\title{
Evidence that the causal agent of bacterial cold- water disease Flavobacterium psychrophilum is transmitted within salmonid eggs
}

\author{
Laura L. Brown ${ }^{1, *}$, William T. Cox ${ }^{2}$, R. Paul Levine ${ }^{1}$ \\ ${ }^{1}$ Hopkins Marine Station, Stanford University, Oceanview Blvd, Pacific Grove, California 93950, USA \\ ${ }^{2}$ California Department of Fish \& Game, Fish Health Lab, 2111 Nimbus Road, Rancho Cordova, California 95670, USA
}

\begin{abstract}
To examine the possibility that Flavobacterium psychrophilum, cause of bacterial coldwater disease (BCWD), may be vertically transmitted, eggs and embryos at selected stages of development were taken from 17 steelhead trout. Some of the broodstock steelhead trout used for this study had been injected with erythromycin prior to spawning; some had been injected with oxytetracycline, and others had not been injected. Surface disinfected eggs/embryos were incubated in tryptone yeast extract (TYE) broth, and egg surfaces were determined to be sterile when no bacteria were isolated from the broth after $72 \mathrm{~h}$ incubation at $17^{\circ} \mathrm{C}$. These eggs/embryos were then homogenized and cultured in TYE broth, and growth was identified as F psychrophilum by biochemical and immunological assays. F psychrophilum contamination was identified from the surface of $28 \%$ of eggs/embryos. F. psychrophilum was also detected within the ovarian fluid samples from $10 \%$ of the broodstock trout, and the bacterium was isolated from the contents of $13 \%$ of newly spawned, surface-disinfected eggs as well as from $7 \%$ of eyed eggs and $4 \%$ of newly hatched alevins. No difference was observed in the proportion of eggs infected with $F$. psychrophilum from antibiotic-injected versus non-injected fish. At the hatchery, however, the remaining progeny of broodstock injected with erythromycin experienced significantly lower mortality due to BCWD up to $10 \mathrm{wk}$ after ponding than the progeny of fish not injected or injected with oxytetracycline. In vitro experiments indicated that $F$. psychrophilum is resistant to lysozyme concentrations of up to $2 \mathrm{mg} \mathrm{m}^{-1}$ (greater than concentrations found within a salmonid egg) and that $2 \%$ of $F$. psychrophilum cells survive after exposure of $100 \mathrm{ppm}$ povidone/iodine for 30 min. The results of this study indicate that $F$. psychrophilum may be transmitted both horizontally and vertically within salmonid hatcheries.
\end{abstract}

KEY WORDS: Cold-water disease Flavobacterium Eggs - Vertical transmission lodine disinfection

\section{INTRODUCTION}

In 1995 high mortalities due to systemic bacterial cold-water disease (BCWD) were documented in steelhead trout Oncorhynchus mykiss in several Northern California hatcheries, including the site of this study, the Big Creek Hatchery, Davenport, California, USA. Losses of up to $85 \%$ during the first 2 mo of rearing were observed in some batches of fish. All of these fish

- Present address: National Research Council of Canada, Institute for Marine Biosciences, 1411 Oxford St., Halifax, Nova Scotia, Canada B3H 3Z1. E-mail: laura.brown@nrc.ca developed systemic BCWD within 1 to $4 \mathrm{wk}$ after transfer from egg incubation trays to hatchery troughs. The eggs and young fish had been incubated in sandfiltered spring water, the source of which is fish-free. Yellow colonies typical of Flavobacterium psychrophilum, causal agent of BCWD (Holt et al. 1993), were isolated on plates of tryptone-yeast extract agar inoculated with surface disinfected steelhead egg homogenates.

The causal agent of BCWD is Flavobacterium psychrophilum. The taxonomic position of this bacterium has changed considerably over past years, and it has been variously designated as Flexibacter psychro- 
philus and Cytophaga psychrophila, the most recent positioning being Flavobacterium psychrophilum (Bernardet et al. 1996).

Bacterial contamination of the surface of the eggs of salmonids and other fishes and of reproductive fluids has been well documented (Shelbourne 1963, Barker et al. 1989, Holt et al. 1993, Rangdale et al. 1996). Cytophaga spp., Flavobacterium spp., and Flexibacter spp. are common among the bacterial species identified (Hansen et al. 1992, Cipriano et al. 1995). The possibility that Flavobacterium psychrophilum is vertically transmitted via the egg has been raised (Borg 1960, Rangdale et al. 1996). The study reported here was initiated in order to determine if F. psychrophilum could be isolated from the contents of steelhead eggs and if egg transmission is a possible route of infection for $F$. psychrophilum. Another objective of the study was to determine whether injection of antibiotics into broodstock lemale steelhead prior to spawning reduces early life-stage mortalities due to BCWD within their progeny.

\section{MATERIALS AND METHODS}

Bacteria. A stock culture of Flavobacterium psychrophilum (isolate 95-7) was used as positive control in the experiments described below. This strain had been originally isolated from the kidney of a rainbow trout Oncorhynchus mykiss at the American River Hatchery, Rancho Cordova, California, USA. Bacteria were grown on TYE agar plates (TYE: tryptone $0.4 \% \mathrm{w} / \mathrm{V}$, yeast extract $0.04 \% \mathrm{w} / \mathrm{v}, \mathrm{CaCl}_{2} 0.02 \% \mathrm{w} / \mathrm{v}, \mathrm{MgSO}_{4}$ $0.05 \% \mathrm{w} / \mathrm{v}, \mathrm{pH} 7.2$, supplemented with $0.5 \% \mathrm{v} / \mathrm{v}$ newborn calf serum), at $17^{\circ} \mathrm{C}$. For bacterial suspensions, cells were aseptically scraped off plates and resuspended in sterile phosphate-buffered saline (PBS) to the desired concentration. For some experiments, Aeromonas salmonicida (isolate donated by T. P. T. Evelyn and J. E. Ketcheson, Department of Fisheries and Oceans Pacific Biological Station, Nanaimo, Canadaj was used for comparative purposes. An At strain was used, and it was grown on TYE and harvested as described for $F$. psychrophilum.

Fish and eggs. Two stocks of steelhead trout from 2 different sources in Northern California were examined. One was from Scott Creek, the second from San Lorenzo River. Both stocks are raised at the Big Creek Hatchery, Kingfisher Flats Project, in Davenport, California. Fish were captured as they returned to their respective home waters to spawn, and were then taken to the hatchery. Five female fish from the Scott Creek (SC) stock were given an intraperitoneal (i.p.) injection of erythromcyin (20 $\mathrm{mg} \mathrm{kg}^{-i}$ fish weight) on arrival at the hatchery and at $30 \mathrm{~d}$ intervals thereafter until spawning. Seven females from the San Lorenzo River (SL) stock were injected i.p. with oxytetracycline (20 $\mathrm{mg} \mathrm{kg}^{-1}$ fish weight) following the same regime. Five additional SL fernales were left uninjected. There were few SC broodstock available at this production hatchery and therefore it was not possible to have a noninjected SC group. Samples of unfertilized, non-waterhardened, non-disinfected eggs ( $n=5$ per fish) were taken from each fish at spawning along with ovarian fluid. The eggs and fluid were transported to the laboratory in sterile containers on ice. The remainder of the eggs from each fish were fertilized, surface disinfected, water-hardened with $100 \mathrm{ppm}$ povidone/iodine for $1 \mathrm{~h}$, and then rinsed and incubated in flowing hatchery water, as per standard hatchery practices. Samples of these freshly disinfected eggs ( $n=10$ per fish) were collected after rinsing. Additional samples were taken from the progeny of each fish at the eyed and pre-hatch stages of development $(n=10$ per fish per development stage). Half of the hatchery-disinfected eggs/embryos were re-disinfected in the laboratory (see next section). Mean ambient water temperature at the hatchery was $9.5^{\circ} \mathrm{C}$.

Isolation of Flavobacterium psychrophilum from eggs and embryos. A modified protocol of Evelyn et al. (1984) was followed, in order to examine the eggs/ embryos for intra-ovum infections and surface contamination due to $F$. psychrophilum. The unfertilized, nonwater-hardened, non-disinfected eggs ( $\mathrm{n}=5$ per fish) transported in ovarian fluid were blotted on sterile filter paper and placed in individual tubes containing $3 \mathrm{ml}$ of TYE broth. At the outset of this study it became apparent that $F$. psychrophilum was contaminating the surface of some of the eggs/embryos (see 'Results and discussion'), despite povidone/iodine disinfection procedures at the hatchery. A decision was made to repeat the surface disinfection procedure on half of the samples of hatchery-disinfected eggs and embryos. Therefore, the disinfected, newly fertilized eggs, eyed eggs, and pre-hatch sac fry were all treated as follows: half of these eggs or embryos ( $n=5$ per development stage per fish) were simply blotted on sterile filter paper and then placed in $3 \mathrm{ml}$ TYE broth. The remaining half ( $\mathrm{n}=$ 5 per stage per fish) were surface disinfected with $400 \mathrm{ppm}$ povidone/iodine (diluted in sterile distilled $\mathrm{H}_{2} \mathrm{O}$ ) for $15 \mathrm{~min}$, after which they were rinsed 5 times with at least 10 volumes of sterile distilled water. The re-disinfected eggs or embryos were blotted and placed in $3 \mathrm{ml}$ TYE broth. All samples were incubated at $17^{\circ} \mathrm{C}$ for $72 \mathrm{~h}$, and the broth examined for turbidity. An aliquot from each the TYE broth samples was aseptically streaked onto TYE plates and incubated at $17^{\circ} \mathrm{C}$ for an additional $72 \mathrm{~h}$ whether or not turbidity was observed. An egg or embryo was only deemed to be surface-disinfected if no turbidity and no subsequent 
growth of F. psychrophilum on TYE plates was observed.

To determine if Flavobacterium psychrophilum was transmitted within the steelhead eggs rather than on the surface, the egg or embryo in any TYE broth that was clear and free of turbidity after $72 \mathrm{~h}$ incubation was crushed and homogenized with a sterile glass rod. The resulting homogenate was then incubated at $17^{\circ} \mathrm{C}$ for an additional $72 \mathrm{~h}$, after which it was streaked onto TYE plates and the plates incubated at $17^{\circ} \mathrm{C}$ for a further $72 \mathrm{~h}$.

Growth on all agar plates was examined for Flavobacterium psychrophilum and growth identified as F. psychrophilum using the following criteria: (1) Gram-negative rods, (2) yellow pigment produced on TYE medium, (3) observation of a red-orange colour when a loopful of cells was streaked onto filter paper soaked in $1 \mathrm{~N} \mathrm{NaOH}$ (indicative of flexirubin, the pigment produced by some Cytophaga spp., Flexibacter spp., and Flavobacterium spp., Stevenson 1992), (4) growth at $17^{\circ} \mathrm{C}$, but not at $30^{\circ} \mathrm{C}$, and (5) observation of a positive slide agglutination within $30 \mathrm{~s}$. Slide agglutination was performed with a saline cell suspension and rabbit antiserum produced against $F$. psychrophilum (supplied by Dr R. P. Hedrick, University of California, Davis, USA). The contents of an egg or embryo were only considered positive for F. psychrophilum if all of the above criteria had been met for the homogenized sample, and if the original egg/embryo surface was deemed to have been sterile.

Survival of Flavobacterium psychrophilum within salmonid eggs. The contents of 50 surface disinfected steelhead eggs from the uninjected SL group were aseptically removed from the eggs with $1 \mathrm{ml}$ syringes and disposable 25 gauge needles. The contents of 5 eggs (10 samples in total) were pooled into 1 sterile Eppendorf tube. Approximately 10 F. psychrophilum (determined by plate-counts of a serially-diluted bacterial cell suspension) were added to each pooled egg content. These spiked egg contents were incubated at $17^{\circ} \mathrm{C}$ for $7 \mathrm{~d}$, after which an aliquot of each sample was streaked onto TYE plates and incubated at $17^{\circ} \mathrm{C}$ for an additional $72 \mathrm{~h}$. Growth was confirmed as F. psychrophilum according to the criteria outlined above.

Susceptibility of Flavobacterium psychrophilum to lysozyme. A modification of the procedure described by Yousif et al. (1994) was followed to determine whether $F$. psychrophilum is resistant or susceptible to lysozyme. Suspensions of F. psychrophilum and Aeromonas salmonicida [positive control for lysozyme activity (Yousif et al. 1994)] were made in PBS and adjusted to an absorbance of 1.0 at $540 \mathrm{~nm}$. The bacteria were diluted $1 / 10$ in solutions of hen egg white lysozyme (Sigma) in PBS ( $\mathrm{pH} 6.2$ ), at concentrations of $0,0.1,1.0$, and $2.0 \mathrm{mg} \mathrm{ml}^{-1}$, equivalent to enzyme activ- ity of $0,5000,50000$, and 100000 units $\mathrm{ml}^{-1}$. The suspensions were incubated at room temperature. Samples of each suspension at each lysozyme concentration were taken at $0,30,60$, and $90 \mathrm{~min}$. The cells were washed once in PBS and then serially diluted 100 -fold to $1 \times 10^{-6}$. Twenty-five $\mu$ l of each diluted sample were dropped, in triplicate, onto TYE plates. The plates were incubated at $17^{\circ} \mathrm{C}$ for $48 \mathrm{~h}$, after which colonies were counted. Results are expressed as the percentage reduction in cell number, using the colony counts from the control tubes ( $0 \mathrm{mg} \mathrm{ml}^{-1}$ lysozyme) as the standard $(0 \%)$ reduction.

Susceptibility of Flavobacterium psychrophilum to povidone/iodine. It was necessary to examine the resistance or susceptibility of $F$. psychrophilum to povidone/iodine, given the apparent failure of the egg surface-disinfection procedure in the hatchery. The same procedure as with the lysozyme experiment was followed, except that the bacterial suspensions (both F. psychrophilum and Aeromonas salmonicida) were exposed to povidone/iodine disinfectant (Argent Chemical Laboratories, USA) at concentrations of 0 , 10,100 , and 500 ppm in sterile, distilled water. Samples were taken at 0,30 and 60 min.

Mortalities resulting from BCWD. The remaining progeny of the 17 experimental fish (antibiotic-injected and non-injected) were reared in the hatchery according to standard hatchery practice. When mortality occurred, the carcasses were examined and bacterial culture performed. Biochemical tests were carried out on selected bacterial isolates for identification. These tests included API-ZYM test strips (API Analytab Products, USA), Gram reaction, oxidase test, production of yellow pigment, flexirubin test, aesculin hydrolysis, nitrate reduction, no growth on Tryptic Soy Agar, evidence of autoagglutination, and no growth at $25^{\circ} \mathrm{C}$. Immunoassays included slide agglutination as described earlier. BCWD was determined as the cause of mortality when Flavobacterium psychrophilum was identified from tissues, characteristic pathological signs were noted (Holt et al. 1993), and bacteria typical of F. psychrophilum were observed in spleen samples examined by phase contrast microscopy at 600 to $1000 \times$ magnification. Statistically significant differences in mortality were determined by 2 -way ANOVA (Sokal \& Rohlf 1981), with significance at $p<0.01$.

\section{RESULTS AND DISCUSSION}

Twenty-eight percent of all of the newly spawned and fertilized eggs, eyed eggs, and yolk sac fry were surface contaminated with Flavobacterium psychrophilum (Table 1). There was no significant difference in the percentage of eggs or embryos positive for 
Table 1. Oncorhynchus mykiss. Percentage (\%) of eggs or embryos positive for Flavobacterium psychrophifum. Scott Creek (SC) and San Lorenzo River (SL) female steelhead trout were injected before spawning with erythromycin (E) ( $\mathrm{n}=5$ fish), oxytetracycline $(O)$ ( $n=7$ fish), or were not injected $(N)(n=5$ fish). Eggs and embryos were examined for surface or internal bacterial contamination. Results for surface contamination are expressed as the average percentage of samples that proved positive ( + ) for $F$. psychrophilum, for all stages ( $\mathrm{n}=5$ per stage per fish). Results of ovarian fluid contamination refer to percentage of eggs positive for F. psychrophilum surface contamination from ovarian fluid ( $\mathrm{n}=5$ per fish). Results for internal contamination are expressed as individual stages ( $n=5$ per stage per fish; these eggs/embryos were re-disinfected). SE: standard error

\begin{tabular}{|c|c|c|c|c|c|c|}
\hline \multirow[t]{2}{*}{ Stock } & \multirow[t]{2}{*}{ Injected with } & \multirow{2}{*}{$\begin{array}{l}+ \text { for surface } \\
\text { contamination }\end{array}$} & \multirow{2}{*}{$\begin{array}{c}+ \text { for ovarian } \\
\text { contamination }\end{array}$} & \multicolumn{3}{|c|}{+ for internal contamination } \\
\hline & & & & Newly fertilized egg & Eyed egg & At hatch \\
\hline $\mathrm{SC}$ & E & 23 & 9 & 15 & 12 & 8 \\
\hline SL & $\mathrm{O}$ & 33 & 12 & 12 & 8 & 2 \\
\hline SL & $N$ & 28 & 10 & 11 & 0 & 2 \\
\hline \multicolumn{2}{|c|}{ Average of all 3 stocks $( \pm \mathrm{SE})$} & $28 \pm 4$ & $10 \pm 1$ & $13 \pm 2$ & $7 \pm 5$ & $4 \pm 3$ \\
\hline
\end{tabular}

surface-contamination between any of the developmental stages. The surface contamination occurred despite the fact that the newly spawned eggs had been surface-disinfected with povidone/iodine at the hatchery. The data suggest that a source of $F$. psychrophilum was the hatchery water itself and that surface-disinfected eggs were being re-inoculated with the waterborne bacterium. F. psychrophilum was also isolated from the surface of $10 \%$ of newly spawned eggs that had only been in contact with ovarian fluid from the spawning female, indicating that the fish were a source of $F$. psychrophilum in these cases, as noted by Holt et al. (1993). Surface disinfection of all eggs immediately after spawning is thus essential to control BCWD, assuming that the water in which the disinfected eggs and embryos are incubated is pathogenfree. The results of the povidone/iodine experiment indicated F. psychrophilum is susceptible to exposure to $100 \mathrm{ppm}$ povidone/iodine for $30 \mathrm{~min}$ because there was a $98 \%$ reduction in the number of culturable $F$.

Table 2. Aeromonas salmonicida and Flavobacterium psychrophilum. Susceptibility to povidone/iodine. Results expressed as \% reduction in colony-forming units (cfu) after exposure to povidone/iodine disinfectant at selected concentrations and exposure times

\begin{tabular}{|cccc|}
\hline $\begin{array}{c}\text { Povidone/iodine } \\
\text { concentration } \\
\text { (ppm) }\end{array}$ & $\begin{array}{c}\% \text { reduction of cfu after exposure to } \\
\text { povidone/iodine }\end{array}$ & $60 \mathrm{~min}$ \\
\hline $\begin{array}{c}\text { Aeromonas salmonicida } \\
0\end{array}$ & 0 & 0 & \\
0 & 0 & 100 & 0 \\
10 & 0 & 100 & 100 \\
100 & 0 & 100 & 100 \\
500 & 0 & & \\
Flavobacterium psychrophilum & & 0 \\
0 & 0 & 0 & 100 \\
10 & 0 & 50 & 100 \\
100 & 0 & 98 & 100 \\
500 & 0 & 100 & \\
\hline
\end{tabular}

psychrophilum. However, the killing effect was not complete and $2 \%$ of the bacteria survived, suggesting that a longer exposure may be necessary (there was $100 \%$ reduction after 60 min exposure). Furthermore, there was only a $50 \%$ reduction in cell numbers at 10 ppm (Table 2). In routine hatchery practices povidone/iodine disinfectants are used in fresh water at concentrations varying from 50 to 100 ppm (Groberg 1988), but the egg:iodophor volume may vary considerably, and therefore not all eggs within a container are exposed to equal iodophor concentrations (Rogers \& Chapman 1991). In certain hatcheries, a percentage of eggs may not be exposed to sufficiently high povidone/iodine concentrations and are therefore not effectively surface-disinfected. Such eggs could act as reservoirs for horizontal and vertical transmission of $F$. psychrophilum.

Flavobacterium psychrophilum was isolated from the contents of $13 \%$ of newly fertilized eggs, as well as from $7 \%$ of eyed eggs and from $4 \%$ of newly hatched alevins, all of which had been surface disinfected in the laboratory (Table 1). To our knowledge this is the first report of isolation of $F$. psychrophilum from the contents of surface-disinfected salmonid eggs. Previously it was thought that Renibacterium salmoninarum, causal agent of bacterial kidney disease, was the only bacterial pathogen that could survive within salmonid eggs (Evelyn et al. 1984, Barker et al. 1991, Yousif et al. 1994). It is likely that egg transmission of $F$. psychrophilum is also a concern.

Susceptibility to lysozyme is a characteristic of many fish pathogens (Grinde 1989). Yousif et al. (1994) have shown that a number of Gram-negative fish pathogens are susceptible to lysozyme purified from coho salmon Oncorhynchus kisutch eggs. However, those authors did not test Flavobacterium psychrophilum for lysozyme susceptibility, but our experiments indicate $F$. psychrophilum is not as susceptible to lysozyme as is Aeromonas salmonicida. Exposure of F. psychrophilum to $2 \mathrm{mg} \mathrm{ml}^{-1}$ for 90 min resulted in only a $44 \%$ reduc- 
Table 3. Aeromonas salmonicida and Flavobacterium psychrophilum. Susceptibulity to hen egg white lysozyme. Results expressed as \% reduction in colony-forming units (cfu) after exposure to lysozyme at selected concentrations and exposure times. PBS: phosphate-buffered saline. Lysozyme actuvity $=50000$ units $\mathrm{mg}^{-1}$

\begin{tabular}{|c|c|c|c|c|}
\hline \multirow{2}{*}{$\begin{array}{c}\text { Lysozyme conc. } \\
\left.\text { (mg ml }{ }^{1}\right) \\
\text { in PBS }\end{array}$} & \multicolumn{4}{|c|}{$\begin{array}{c}\text { "n reduction of cfu after exposure } \\
\text { to lysozyme }\end{array}$} \\
\hline & $0 \mathrm{~min}$ & $30 \mathrm{~min}$ & $60 \mathrm{~min}$ & $90 \mathrm{~mm}$ \\
\hline \multicolumn{5}{|c|}{ Aeromonas salmonicida } \\
\hline 0.0 & 0 & 0 & 0 & 0 \\
\hline 0.1 & 1 & 56 & 74 & 53 \\
\hline 1.0 & 2 & 56 & 78 & 67 \\
\hline 2.0 & 1 & 99 & 98 & 99 \\
\hline \multicolumn{5}{|c|}{ Flavobacterium psychrophilum } \\
\hline 0.0 & 0 & 0 & 0 & 0 \\
\hline 0.1 & 0 & 20 & 0 & 31 \\
\hline 1.0 & 0 & 10 & 60 & 46 \\
\hline 2.0 & 0 & 30 & 55 & 44 \\
\hline
\end{tabular}

tion in the number of viable cells compared to a $99 \%$ reduction in $A$. salmonicida cell numbers when the latter was exposed under the same conditions (Table 3 ). This lysozyme concentration is comparable to that found by Yousif et al. (1994) in salmonid eggs, even though the lysozyme used for the experiment reported here was derived from hen egg whites and not from salmonid eggs. These data are supported by the results obtained from the experimentally infected egg contents experiment in which live, culturable F. psychrophilum was isolated from $100 \%$ of the infected egg contents (data not shown). Seemingly, F. psychrophilum is unlikely to be susceptible to salmonid egg lysozyme.

There was no significant difference in the prevalence of Flavobacterium psychrophilum infections within eggs and embryos from antibiotic injected versus non-injected broodstock (Table 1). Nor was there a significant difference in the prevalence of surface contamination due to $F$. psychrophilum within the ovarian fluid of antibiotic-injected versus non-injected female broodstock (Table 1). However, there was significantly lower mortality resulting from BCWD within the progeny of SC stock injected with erythromycin, than within the progeny of the SL fish, either injected with oxytetracycline or not injected (Fig. 1). When considering the contrasting in vitro and in vivo data, it should be remembered that the in vitro examination of the prevalence of $F$. psychrophilum infections within eggs and embryos utilized an enhancement technique. The bacteria were isolated under optimized conditions, from within eggs and embryos in nutrient-rich media. In contrast, mortality due to BCWD observed in the hatchery occurred in less than ideal conditions for bacterial growth, at lower temperatures, in the absence of

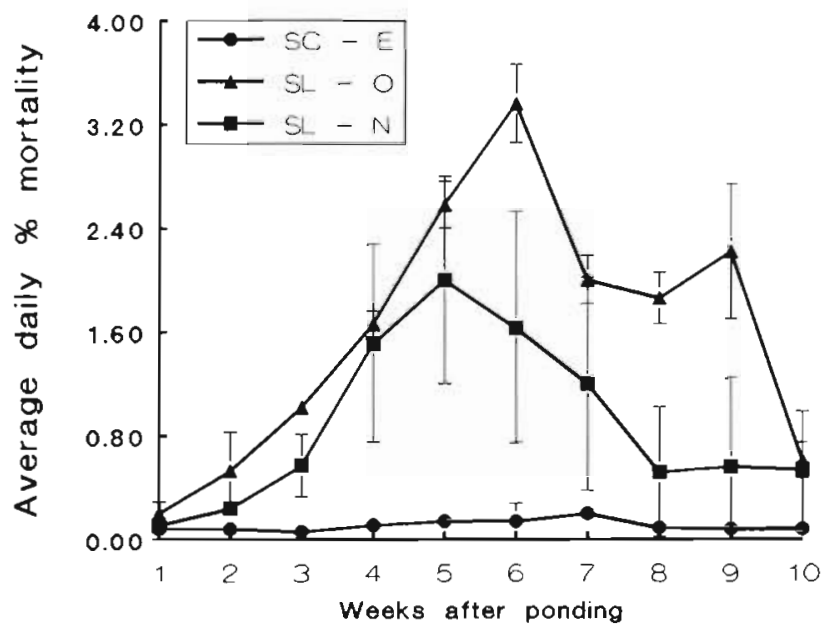

Fig. 1. Oncorhynchus mykiss. Average daily $\%$ mortalities due to bacterial cold-water disease within progeny of Scott Creek (SC) and San Lorenzo River (SL) steelhead broodstock that were injected with either erythromycin (E), oxytetracycline $(O)$, or were not injected $(N)$, before spawning. $n=$ 16000 to 25000 per stock. Error bars = standard error

nutrient-rich media and the presence of the animal's developing immune system. Thus, broodstock injection of erythromycin may be more effective than oxytetracycline at reducing early mortality due to BCWD, although intra-ovum infections due to $F$. psychrophilum may not be completely eliminated. However, the observed differences in mortality may also have been the result of genetic differences, because the erythromycin-injected fish were from a different stock (SC) than those injected with oxytetracycline and those not injected (SL). It is also possible the SC fish were infected with a less virulent strain of $F$. psychrophilum than the SL strains; however, this would not be the case for water-borne bacteria that contaminated the surface of the eggs, as all the eggs were reared on the same water source. Complete strain differentiation was not possible in this study.

Flavobacterium psychrophilum isolated from the contents of the newly spawned eggs, and eyed eggs (Table 1) may have been located within the perivitelline space of the eggs, rather than the yolk itself. It was not possible to determine this in the experiments described here. However, in light of the data obtained from the lysozyme experiment (Table 3), and from the experimentally infected egg contents, it seems that $F$. psychrophilum is well able to survive within the contents of salmonid eggs.

Surface contamination due to the presence of Flavobacterium psychrophilum within the water is a serious concern for hatcheries. The hatchery in this study has a fish-free water source. However, amphibians, insects, snails, and possibly other animals may be reservoirs of 
F. psychrophilum infection. Samples of salamanders and newts were removed from the hatchery water and cultures taken from brain tissue. F. psychrophilum was isolated from one newt (lab of W.T.C., data not presented). Our data indicate that the time of exposure to iodophor as well as the in situ concentration of the disinfectant may be important in ensuring complete disinfection. From the results of this study it seems there are several routes of infection due to $F$. psychrophilum in salmonids. Horizontal transmission appears likely because of the presence of $F$. psychrophilum on egg surfaces after disinfection in the hatchery, indicating $F$. psychrophilum in the water supply. Transmission within and on the egg, as demonstrated in this study, is a major concern. Further work to examine the efficacy of broodstock injection with antibiotics as a means of controlling BCWD in early life stages of salmonids is required.

Acknowledgements. The authors are extremely grateful to Mr Dave Streig and the staff of the Big Creek Hatchery, Davenport, California, for technical assistance, and to Ms T. Veek for additional technical assistance and for her review of the manuscript. Thanks are due to Dr T P. T. Evelyn and Mr J. E. Ketcheson, Department of Fisheries and Oceans Pacific Biological Station, Nanaimo, Canada for kindly donating the Aeromonas salmonicida isolate, and to Dr R. P. Hedrick, University of California, Davis, USA, for the generous donation of the rabbit anti-Flavobacterium psychrophilum serum. We also thank Dr W J. Groberg Jr for critically reviewing the manuscript. This project was supported, in part, by the California Department of Fish and Game. L.L.B. was supported by a Natural Sciences and Engineering Research Council of Canada Post-Doctoral Fellowship. Contribution NRC No. 39744 .

\section{LITERATURE CITED}

Barker GA, Smith SN, Bromage NR (1989) The bacterial flora of rainbow trout, Salmo gairdneri Richardson and brown trout, Salmo trutta L., eggs and its relationship to developmental success. J Fish Dis 12:281-293

Barker GA, Smith SN, Bromage NR (1991) Commensal bacteria and their possible relationship to the mortality of incubating salmonid eggs. J Fish Dis 14:199-210

Bernardet JF, Segers P, Vancanneyt M, Berthe F, Kersters K, Vandamme P (1996) Cutting the Gordian knot: emended

Responsible Subject Editor: D. W. Bruno, Aberdeen, Scotland, UK classification and description of the genus Flavobacterium, emended description of the Family Flavobacteriaceae, and proposal of Flavobacterium hydatis nom. nov. (basonym, Cytophaga aquatilis Strohl and Tait 1978). Int J Syst Bacteriol 46:128-148

Borg AF (1960) Studies on myxobacteria associated with diseases in salmonid fishes. Wildlife Disease 8, American Association tor the Advancement of Science. Washington, DC

Cipriano RC, Ford LA, Teska JD (1995) Association of Cytophaga psychrophila with mortality among eyed eggs of Atlantic salmon (Salmo salar). J Wildlife Dis 31:166-171

Evelyn TPT, Prosperi-Porta L, Ketcheson JE (1984) The salmonid egg as a vector for the kidney disease bacterium Renibacterium salmoninarum. In: ACUIGRUP (ed) Fish diseases, 4th COPRAQ Session, Cadiz, Spain. Editora ATP, Madrid, p 111-117

Grinde B (1989) Lysozyme from rainbow trout, Salmo gairdneri Richardson, as an antibacterial agent against fish pathogens. J Fish Dis 12:95-104

Groberg WJ Jr (1988) Observations on water-hardening salmonid eggs in iodophore. In: Proceedings of the 38th Annual Northwest Fish Culture Conference. Fife, Washington, December 1987, p 23-24

Hansen GH, Bergh OJ, Michaelson J, Knappskog D (1992) Flexibacter ovolyticus sp. nov., a pathogen of eggs and larvae of Atlantic halibut, Hippoglossus hippoglossus L. Int J Syst Bacteriol 42:451-458

Holt RA, Rohovec JS, Fryer JL (1993) Bacterial cold-water disease. In: Inglis V, Roberts RJ, Bromage NR (eds) Bacterial diseases of fish. Blackwell Scientific Publications, Oxford, p $3-23$

Rangdale RE, Richards RE, Alderman DJ (1996) Isolation of Cytophaga pschrophila, causal agent of rainbow trout fry syndrome (RTFS) from reproductive fluids and egg surfaces of rainbow trout (Oncorhynchus mykiss). Bull Eur Assoc Fish Pathol 16:63-67

Rogers RW, Chapman PF (1991) Variation in iodine concentration during water hardening of salmonid eggs. Washington Department of Fisheries Informational Report \#5, Olympia, WA

Shelbourne JE (1963) A marine fish-rearing experiment using antibiotics. Nature 198:74-75

Sokal RS, Rohlf FJ (1981) Biometry. The principles and practice of statistics in biological research, 2 nd edn. WH Freeman \& Co, New York

Stevenson RMW (1992) A field guide to systematic bacteriology, laboratory manual. University of Guelph, Guelph, Ontario

Yousif AN, Albright LJ, Evelyn TPT (1994) In vitro evidence for the antibacterial role of lysozyme in salmonid eggs. Dis Aquat Org 19:15-19

Manuscript first received: October 21, 1996

Revised version accepted: March 14, 1997 